\title{
Increasing Activity and Learning Outcomes of Class Xi Tkj Smk Muhammadiyah 1 Moyudan in Network Service Technology Subjects Through the Tai Learning Model (Team Accelerated Instruction)
}

\author{
Yazid Afifudin Abror \\ Informatics Engineering Education Study Program, Faculty of Engineering, Universitas Negeri yogyakarta
}

$\begin{array}{r}\hline \text { ARTICLEINFO } \\ \hline \text { Article history: } \\ \text { Received Dec 22, } 2020 \\ \text { Revised Jan 15, } 2021 \\ \text { Accepted Jan 27, } 2021 \\ \hline\end{array}$

Keywords:

Team Accelerated Instruction; Student activity; Student learning outcomes.

\begin{abstract}
This study aims to increase the activeness and learning outcomes of class XI TKJ A SMK Muhammadiyah 1 Moyudan in the subject of network service technology using the TAl (Team Accelerated Instruction) learning model. The data collection method in this study used the method of observation, learning outcomes tests, and documentation. This analysis is applied by processing the activity scores and the average student learning outcomes test scores, calculating the percentage, presenting the data, then drawing conclusions. The most prominent increase occurred in mental activity which increased by $20.60 \%$. This is evidenced by the percentage of student activity at the end of the cycle is $80.43 \%$, which means an increase from the initial data or baseline (51.19\%). At the end of the cycle, the average score of students was 79.14, which means an increase from the initial data or baseline (66). The most prominent increase occurred in mental activity which increased by $20.60 \%$. The conclusion obtained based on this research is that the implementation of the TAI (Team Accelerated Instruction) cooperative learning model can increase student activity and student learning outcomes. This is evidenced by the percentage of student activity at the end of the cycle is $80.43 \%$, which means an increase from the initial data or baseline $(51.19 \%)$. At the end of the cycle, the average score of students was 79.14, which means an increase from the initial data or baseline (66). The most prominent increase occurred in mental activity which increased by $20.60 \% .43 \%$ which means an increase from the initial data or baseline (51.19\%). At the end of the cycle, the average score of students was 79.14, which means an increase from the initial data or baseline (66). The most prominent increase occurred in mental activity which increased by $20.60 \%$. 43\% which means an increase from the initial data or baseline $(51.19 \%)$. At the end of the cycle, the average score of students was 79.14, which means an increase from the initial data or baseline (66). The most prominent increase occurred in mental activity which increased by $20.60 \%$.
\end{abstract}

This is an open access article under the CC BY-NC license.

\section{Corresponding Author:}

Yazid Afifudin Abror,

Informatics Engineering Education Study Program,

Faculty of Engineering, Universitas Negeri Yogyakarta

E-mail: yazidabron12@gmail.com 


\section{INTRODUCTION}

Education is an important factor. The function of education is to print quality human resources(Sugiarto, 2012). Vocational High School (SMK) is one of the educational institutions that is responsible for equipping students with knowledge, skills, and expertise. According to Permendiknas number 22 of 2006 explains that vocational education aims to improve intelligence, knowledge, noble character, and skills of students to live independently and participate in further education in accordance with their vocational program.(Kurniawati \& Sayuti, 2013).

Vocational High Schools provide a variety of expertise programs that have their respective skills and advantages according to their field of expertise. SMK Muhammadiyah 1 Moyudan is a vocational high school that organizes several skill programs that equip students with the knowledge and skills to make SMK graduates ready to enter the world of work. One of the expertise programs held at SMK Muhammadiyah 1 Moyudan is the Computer and Network Engineering (TKJ) expertise program. Network Service Technology (TLJ) is one of the subjects taught in the TKJ area of expertise at SMK Muhammadiyah 1 Moyudan(Jambak, 2013).

Based on the results of interviews conducted on August 7, 2019 with Mr. Iwan Junaedi, ST as a teacher of the Network Service Technology (TLJ) subject at SMK Muhammadiyah 1 Moyudan, students have difficulty understanding the competence of Data Communication Standards. Students who do not understand the material are ashamed to ask the teacher. This is indicated by the fact that when the teacher gives the opportunity to ask questions, not many students ask questions. When the teacher asks questions, students wait for the teacher to appoint before answering. Another problem is the lecture method used by the teacher is still not effective. The implementation of learning is still running in one direction and is monotonous so that student learning activity is still low.

Based on the results of interviews with teachers, the average student activity is still $51.19 \%$ with details; visual activities (paying attention to teachers or friends who are delivering subject matter/ideas/opinions) by $71 \%$, verbal activities (delivering/stating ideas verbally during group discussions) by $29 \%$, listening activities (listening to descriptions/explanations/opinions/discussions from teachers and friends) by $64 \%$, activity metrics (actively involved in learning, especially the TAI process) by $36 \%$, mental activity (responding to/refuting the opinions/ideas of friends or teachers) by $54 \%$, and emotional activities (putting interest/spirit/passion to the learning process) by $54 \%$. While the average student learning outcomes are still at number 66.

From the various problems found, it is necessary to need a cooperative learning method that can encourage student interest in learning XI TKJ A SMK Muhammadiyah 1 Moyudan. So in this study will use a cooperative learning model type Team Accelerated Instruction (TAI) because the above problems are in accordance with the characteristics that exist in the TA type learning model.(Isnaeni, 2015).

\section{METHOD}

The method used in this study is a qualitative descriptive method and for

calculate the data using quantitative(Mulyadi, 2011). The research design used by the researcher is the CAR design from Kemmis \& McTaggart. The first stage in this research cycle is planning, then the action and observation stages are carried out almost simultaneously. After that, it was continued with the reflection stage to conclude what had happened in the learning after the implementation of the research. XI TKJ A SMK Muhammadiyah 1 Moyudan.

1. Research Scenario following:

In its implementation, the research will be carried out through several steps, including the

a. Pre Cycle

At this stage, an agreement was obtained that the implementation of the Team Accelerated Instruction (TAI) learning method would be implemented in the class with 2 cycles. Cycle I will be held on 3 \& 6 September 2019. While Cycle II will be held on 10 \& 12 September 2019. The class agreement that will be given action is in class XI TKJ A SMK Muhammadiyah 1 Moyudan.

Yazid Afifudin Abror, Increasing Activity and Learning Outcomes of Class Xi Tkj A Smk Muhammadiyah 1 Moyudan in Network Service Technology Subjects Through the Tai Learning Model (Team Accelerated 
2. Method of collecting data

The method of data collection in this research is to use several methods, including the following:

a. Observation Method

The observations carried out require written guidelines that contain the indicators to be observed. Based on the indicators that have been set previously, the aspects to be observed are the classroom atmosphere in learning, the level of asking questions in a group, and the curiosity of each student. To obtain the desired data, the researcher limited the preparation of the observation method to only the activity of students who could be observed during the learning process.

b. Test

(Razi, nd)explains that the test is a set of tasks that must be done or a number of questions that must be answered by students to measure their level of understanding and mastery of the required material coverage and in accordance with certain teaching objectives.

c. Documentation

Documentation in the form of photos and important documents in conducting research. Examples of important documents in this research are the Syllabus, Lesson Plans (RPP), Question Sheets, Answer Sheets, Student Score Lists, Group Lists and so on.

\section{RESULTS AND DISCUSSIONS}

\subsection{Results}

Observations were carried out together with the implementation of actions in cycle II. The goal is to observe the activity of class XI TKJ A SMK Muhammadiyah 1 Moyudan students according to the observation guidelines that have been made. Observation of the activity of class XI TKJ A SMK Muhammadiyah 1 Moyudan students was carried out using an observation sheet consisting of eight indicators. Activity data of class XI TKJ A SMK Muhammadiyah 1 students

Moyudan can be seen in the following table:

Table 1.

Student activity in Cycle I

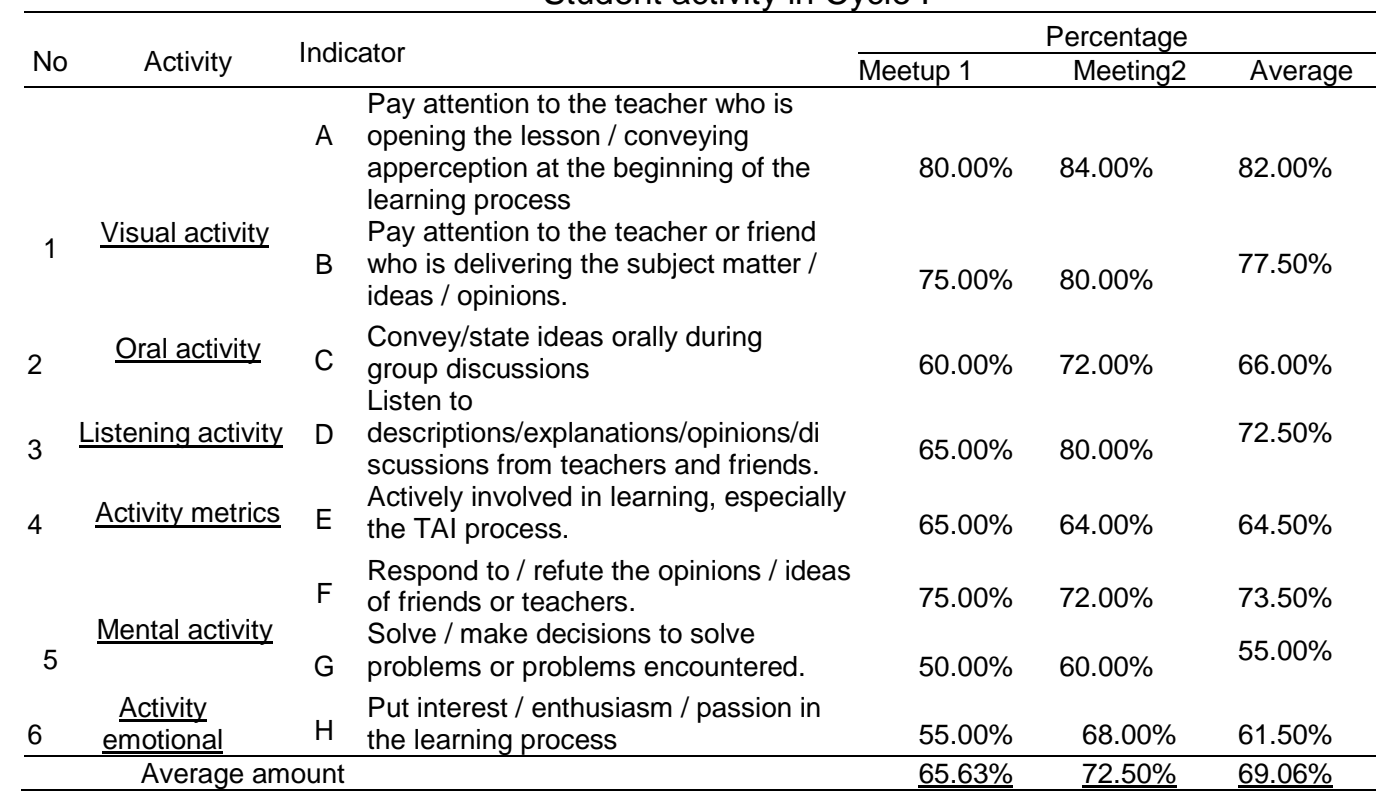


Based on the table above, it can be seen that the activity of class XI TKJ A SMK Muhammadiyah 1 Moyudan students in the first cycle, has a percentage of $69.06 \%$. This percentage has reached the target for each cycle, because in the application of the Cooperative Learning Method Type Team Accelerated Instruction (TAI) the activeness of class XI TKJ A SMK Muhammadiyah 1 Moyudan students in Cycle I the target is $58 \%$. In addition to student activity, student learning outcomes were also observed after carrying out learning activities using the TAl cooperative learning method. Learning outcomes were observed using learning outcomes tests. Data on student learning outcomes test results can be seen in the following table:

Table 2.

Learning outcomes test scores 1 .

\begin{tabular}{ccc}
\hline Serial number & Student's name & Mark \\
\hline 1 & Student 1 & 96 \\
2 & Student 2 & 82 \\
3 & Student 3 & 70 \\
4 & Student 4 & 72 \\
5 & Student 5 & 87 \\
6 & Student 6 & 96 \\
7 & student 7 & 51 \\
8 & student 8 & 68 \\
9 & student 9 & - \\
10 & student 10 & 82 \\
11 & Student 11 & 62 \\
12 & student 12 & 52 \\
13 & student 13 & 86 \\
14 & Student 14 & 63 \\
15 & student 15 & 71 \\
16 & 16 student & 75 \\
17 & 17 student & 73 \\
18 & 18 student & 76 \\
19 & 19 student & - \\
20 & student 20 & 90 \\
\hline
\end{tabular}

The average score of students in the Cycle I learning outcomes test was 73 . The average showed an increase compared to (66) which was used as the baseline. Observations were carried out together with the implementation of actions in cycle II. The goal is to observe the activity of class XI TKJ A SMK Muhammadiyah 1 Moyudan students according to the observation guidelines that have been made. Observation of the activity of class XI TKJ A SMK Muhammadiyah 1 Moyudan students was carried out using an observation sheet consisting of eight indicators. The activity data of class XI TKJ A SMK Muhammadiyah 1 Moyudan students can be seen in the following table:

Table 2.

Learning outcomes test scores 1 .

\begin{tabular}{|c|c|c|c|c|c|c|}
\hline \multirow[b]{2}{*}{ No } & \multirow[b]{2}{*}{ Activity } & \multirow{2}{*}{\multicolumn{2}{|c|}{ Indicator }} & \multicolumn{3}{|c|}{ Percentage } \\
\hline & & & & Meetup 1 & Meeting2 & Average \\
\hline & & A & $\begin{array}{l}\text { Pay attention to the teacher who is } \\
\text { opening the lesson / conveying } \\
\text { apperception at the beginning of the } \\
\text { learning process }\end{array}$ & $87.50 \%$ & $89.29 \%$ & $88.39 \%$ \\
\hline 1 & Visual activity & $B$ & $\begin{array}{l}\text { Pay attention to the teacher or friend } \\
\text { who is delivering the subject matter / } \\
\text { ideas / opinions. }\end{array}$ & $83.33 \%$ & $85.71 \%$ & $84.52 \%$ \\
\hline 2 & Oral activity & C & $\begin{array}{l}\text { Convey/state ideas orally during } \\
\text { group discussions } \\
\text { Listen to }\end{array}$ & $87.50 \%$ & $71.43 \%$ & $73.21 \%$ \\
\hline 3 & Listening activity & D & $\begin{array}{l}\text { descriptions/explanations/opinions/di } \\
\text { scussions from teachers and friends. }\end{array}$ & $75.00 \%$ & $82.14 \%$ & $84.82 \%$ \\
\hline
\end{tabular}

Yazid Afifudin Abror, Increasing Activity and Learning Outcomes of Class Xi Tkj A Smk Muhammadiyah 1 Moyudan in Network Service Technology Subjects Through the Tai Learning Model (Team Accelerated 


\begin{tabular}{|c|c|c|c|c|c|c|}
\hline \multirow[b]{2}{*}{ No } & \multirow[b]{2}{*}{ Activity } & \multirow{2}{*}{\multicolumn{2}{|c|}{ Indicator }} & \multicolumn{3}{|c|}{ Percentage } \\
\hline & & & & Meetup 1 & Meeting2 & Average \\
\hline 4 & Activity metrics & $E$ & $\begin{array}{l}\text { Actively involved in learning, especially } \\
\text { the TAl process. }\end{array}$ & $65.00 \%$ & $82.14 \%$ & $80.65 \%$ \\
\hline & & $\mathrm{F}$ & $\begin{array}{l}\text { Respond to / refute the opinions / ideas } \\
\text { of friends or teachers. }\end{array}$ & $75.00 \%$ & $72.00 \%$ & $73.50 \%$ \\
\hline 5 & Mental activity & G & $\begin{array}{l}\text { Solve / make decisions to solve } \\
\text { problems or problems encountered. }\end{array}$ & $50.00 \%$ & $60.00 \%$ & $55.00 \%$ \\
\hline 6 & emotional & $\mathrm{H}$ & $\begin{array}{l}\text { Put interest / enthusiasm / passion in } \\
\text { the learning process }\end{array}$ & $55.00 \%$ & $68.00 \%$ & $61.50 \%$ \\
\hline & Average amc & ount & & $\underline{82.29 \%}$ & $\underline{78.57 \%}$ & $\underline{80.43 \%}$ \\
\hline
\end{tabular}

Based on the table above, it can be seen that the activeness of class XI TKJ A SMK Muhamnmadiyah 1 Moyudan students in the second cycle has a percentage of $80.43 \%$. This percentage has reached the target for each cycle, because in the application of the Team Accelerated Instruction (TAl) Cooperative Learning Method, the activeness of class XI students of TKJ A SMK Muhammadiyah 1 Moyudan the target is $75 \%$. In addition to student activity, student learning outcomes were also observed after carrying out learning activities using the TAl cooperative learning method. Learning outcomes were observed using learning outcomes tests. Student learning outcomes test data can be seen in the following table:

Table 3.

Learning outcomes test scores 1.

\begin{tabular}{ccc}
\hline Serial number & Student's name & Mark \\
\hline 1 & Student 1 & 81 \\
2 & Student 2 & 83 \\
3 & Student 3 & 88 \\
4 & Student 4 & 83 \\
5 & Student 5 & 85 \\
6 & Student 6 & 91 \\
7 & student 7 & 59 \\
8 & student 8 & 83 \\
9 & student 9 & 83 \\
10 & student 10 & 68 \\
11 & Student 11 & 80 \\
12 & student 12 & 83 \\
13 & student 13 & 75 \\
14 & Student 14 & 67 \\
15 & student 15 & 59 \\
16 & 16 student & 93 \\
\hline \multicolumn{3}{c}{ Average } \\
\hline
\end{tabular}

The average score of students is 79.14. This shows an increase compared to the first cycle of 73.00.

\subsection{Discussion of Research Results}

This study aims to increase student activity and student learning outcomes at SMK Muhammadiyah 1 Moyu and class XI TKJ A. The application of the TAl cooperative learning model is used to achieve this goal. This research is based on the low activity of class XI TKJ A SMK Muhammadiyah 1 Moyudan students in participating in the learning process which causes student learning outcomes to be not optimal.

The results of the observations showed that the average percentage of student activity in the first cycle was $69.06 \%$ and the average student learning outcomes test scores reached 73.00. The average score of students in the test of learning outcomes showed an increase compared to $(66.00)$ which was used as a baseline for research on student learning outcomes. 
In cycle I, of course, there are obstacles that hinder the research process. In the second cycle the average percentage of student activity was $80.43 \%$ and the average student learning outcomes test scores reached 79.14. This shows an increase in the percentage of student activity by $11.37 \%$ and the average test score for student learning outcomes increases by 6.14. For more details, the following table presents a comparison of student activity and a table on the average test scores for student learning outcomes.

Table 3.

The percentage of student activity.

\begin{tabular}{|c|c|c|c|c|c|c|}
\hline \multirow[b]{2}{*}{ No } & \multirow[b]{2}{*}{ Activity } & \multirow{2}{*}{\multicolumn{2}{|c|}{ Indicator }} & \multicolumn{2}{|c|}{ Percentage } & \multirow{2}{*}{ Change } \\
\hline & & & & Cycle 1 & Cycle 2 & \\
\hline & & A & $\begin{array}{l}\text { Pay attention to the teacher who is opening } \\
\text { the lesson / conveying apperception at the } \\
\text { beginning of the learning process }\end{array}$ & $82.00 \%$ & $88.39 \%$ & $6.39 \%$ \\
\hline 1 & Activity_visual & B & $\begin{array}{l}\text { Pay attention to the teacher or friend who is } \\
\text { delivering the subject matter / ideas / } \\
\text { opinions. }\end{array}$ & $77.50 \%$ & $84.52 \%$ & $7.02 \%$ \\
\hline 2 & Oral_activity & C & $\begin{array}{l}\text { Convey/state ideas orally during group } \\
\text { discussions }\end{array}$ & $66.00 \%$ & $73.21 \%$ & $7.21 \%$ \\
\hline 3 & Activity listen & $\mathrm{D}$ & $\begin{array}{l}\text { Listen to } \\
\text { descriptions/explanations/opinions/discussio }\end{array}$ & $72.50 \%$ & $84.82 \%$ & $12.32 \%$ \\
\hline 4 & Activitymetric & $E$ & $\begin{array}{l}\text { Actively involved in learning, especially } \\
\text { the TAl process. }\end{array}$ & $64.50 \%$ & $80.65 \%$ & $16.15 \%$ \\
\hline & Activitymental & $\mathrm{F}$ & $\begin{array}{l}\text { Responding to/refuting the opinions/ideas } \\
\text { of friends or teachers. }\end{array}$ & $73.50 \%$ & $83.04 \%$ & $9.54 \%$ \\
\hline 5 & & G & $\begin{array}{l}\text { Solve / make decisions to solve problems } \\
\text { or problems encountered. }\end{array}$ & $55.00 \%$ & $75.60 \%$ & $20.60 \%$ \\
\hline 6 & Activityemotional & $\mathrm{H}$ & $\begin{array}{l}\text { Put interest / enthusiasm / passion in } \\
\text { the learning process }\end{array}$ & $61.50 \%$ & $73.21 \%$ & $11.71 \%$ \\
\hline Aver: & ge amount & & & $69.06 \%$ & $80.43 \%$ & $11.37 \%$ \\
\hline
\end{tabular}

Table 3.

The percentage of student activity.

\begin{tabular}{rlllc}
\hline \multicolumn{5}{c}{ Student activity percentage } \\
\hline \multirow{2}{*}{ Baseline } & \multicolumn{3}{c}{ Cycle 1 } & Cycle 2 \\
& Meeting 1 & Meeting 2 & Meeting 1 & Meeting 2 \\
\multirow{2}{*}{$51 \%$} & $65.63 \%$ & $72.50 \%$ & $82.29 \%$ & $78.57 \%$ \\
\cline { 2 - 5 } & Average : $69.06 \%$ & Average : $80.43 \%$ \\
\hline
\end{tabular}

\section{Table 3.}

The percentage of student activity.

\begin{tabular}{ccc}
\hline \multicolumn{3}{c}{ Average student learning outcomes test scores } \\
\hline Baseline & Cycle 1 & Cycle 2 \\
66 & 73 & 79.14 \\
\hline
\end{tabular}

The comparison table of activity and learning outcomes of class XI TKJ A SMK Muhammadiyah 1 Moyudan students through the application of learning with the TAI model obtained through observation shows an increase.

The following are conclusions that can be drawn from each indicator:

a. Pay attention to the teacher who is opening the lesson / conveying apperception at the beginning of the learning process.

The activeness of students paying attention to the teacher when opening lessons tends to be high. This is because students do not feel bored with the learning process. In the first cycle, student activity was $82.00 \%$ and increased by $6.39 \%$ to $88.39 \%$ in the second cycle. The increase that occurred in cycle II occurred because students wanted to better understand the planning of the learning process that had been carried out in cycle I. 
b. Pay attention to the teacher or friend who is delivering the subject matter / ideas / opinions. The percentage increase of $7.02 \%$ occurred in this indicator from $77.50 \%$ in the first cycle to $84.52 \%$ in the second cycle. This is thought to occur because students' interest in participating in learning is high. In addition, students also want to know the material to be studied for discussion according to their respective groups and also understand what was conveyed by their friends during the discussion.

c. Convey/state ideas orally during group discussions.

In the first cycle, the students still did not seem to fully understand the new learning model. Students tend to chat about unimportant things during group discussions. In the first cycle this indicator is $66.00 \%$. In cycle II students have begun to understand the need for discussion to better understand the material. There was an increase to $73.21 \%$.

d. Listen to descriptions/explanations/opinions/discussions from teachers and friends.

In the first cycle the percentage is $72.50 \%$. In the second cycle, it increased by $12.32 \%$ to $84.82 \%$. Most of the students are active although there are still some students who are less active on this indicator. It is seen that students listen to each other's descriptions from the teacher and friends.

e. Actively involved in learning, especially the TAl process.

In general, most students are actively involved in learning using this TAI model. In the first cycle, student activity was $64.50 \%$. In the first cycle, students still did not fully understand this TAl-based implementation. Student activities are still dominated by adaptation activities or following the system applied. In the second cycle, students' understanding of TAl increased. Student involvement increased by $16.15 \%$ to $80.65 \%$.

\section{CONCLUSION}

Based on the results of the research and discussion in the previous chapter, it can be concluded that the application of the Team Accelerate Instruction (TAI) type of cooperative learning model increases the activity of class XI TKJ A SMK Muhammadiyah 1 Moyudan students. Based on observation data, the initial percentage (baseline) of student activity in participating in classroom learning before the implementation of TAl was $51.19 \%$, increased to $69.06 \%$ in Cycle I and increased to $80.43 \%$ in Cycle II. The most significant increase occurred in mental activity which increased by $20.60 \%$. The application of the Team Accelerated Instruction (TAI) learning model also improves student learning outcomes. This is indicated by the test data of student learning outcomes. The average value of student learning outcomes before the implementation of TAI is 66 , in the first cycle to 73 then increased in the second cycle to 79.14. The percentage of students who met the KBM at baseline was $39 \%$ (11 students), then in cycle 1 it was $40 \%$ ( 11 children), then in cycle 2 it was $75 \%$ ( 21 children). From these two things, it can be said that learning is successful because it has met at least $75 \%$ of active students and meet KBM standards.

\section{References}

Isnaeni, H. D. (2015). Penerapan Model Pembelajaran Kooperatif Tipe Team Accelerated Instruction (TAI) Untuk Meningkatkan Minat Dan Prestasi Belajar Siswa Kelas XII IPA 2 SMA Negeri 3 Bojonegoro Pada Pokok Bahasan Matrik Tahun Pelajaran 2012/2013. Jurnal Pendidikan Edutama, 2(2), 1-16.

Jambak, I. N. (2013). PENGARUH MODEL PEMBELAJARAN MIND MAPPING TERHADAP HASIL BELAJAR MERAKIT PERSONAL KOMPUTER (MPC) PADA SISWA KELAS X BIDANG KEAHLIAN TEKNIK KOMPUTER JARINGAN DI SMK NEGERI 1 KUTALIMBARU TA 2013/2014. UNIMED.

Kurniawati, P. I., \& Sayuti, S. A. (2013). Manajemen Sarana dan Prasarana di SMK N 1 Kasihan Bantul. Jurnal Akuntabilitas Manajemen Pendidikan, 1(1), 98-108.

Mulyadi, M. (2011). Penelitian kuantitatif dan kualitatif serta pemikiran dasar menggabungkannya. Jurnal Studi Komunikasi Dan Media, 15(1), 128-137.

Razi, F. (n.d.). KONSEP DASAR EVALUASI PEMBELAJARAN Oleh.

Sugiarto, T. (2012). Program Pendidikan Anak Usia Dini (PAUD): Suatu Usaha Untuk Menyiapkan Sumber Daya Manusia Berkualitas di Masa Depan. 